\title{
Relationship between Serum Interleukin-6 Levels and Bronchopulmonary Dysplasia in Preterm Infants at 28-34 Weeks’ Gestation with Respiratory Distress Syndrome
}

\author{
Ayu Alia*, Fiva A Kadi, Tetty Yuniati, Aris Primadi, Sjarief Hidajat, Abdurachman Sukadi \\ Department of Child Health, Universitas Padjadjaran, Bandung, Indonesia \\ *Corresponding author: raay_id@yahoo.com
}

Received December 03, 2018; Revised January 07, 2019; Accepted February 25, 2019

\begin{abstract}
Respiratory distress syndrome (RDS) remains a major cause of mortality and morbidity among preterm infants, especially in developing countries. Up to $40 \%$ of those infants who do survive RDS may develop bronchopulmonary dysplasia (BPD). The aim of this study is to find out the relationship between serum IL-6 levels and BPD in preterm infants at 28-34 weeks' gestation with RDS. A cross sectional study was carried out in Department of Child Health Hasan Sadikin General Hospital Bandung in June-September 2018. Serum samples collected within 6-12 hours after birth. Respiratory distress syndrome was diagnosed on the basis of radiographic findings, respiratory distress, and an increasing oxygen requirement. Bronchopulmonary dysplasia was diagnosed based on the requirement of supplemented oxygen by at least 28 days at 36 weeks of post menstrual age (PMA). Serum IL-6 levels were measured using enzyme-linked immunosorbent assay (ELISA). Data was analyzed using logistic regression. Sixty-eight neonates were studied. Ten developed BPD and 58 were not. Based on logistic regression showed that an increase of $1 \mathrm{pg} / \mathrm{mL}$ of serum IL-6 levels from the normal values examined at $6-12$ hours after birth in preterm infants at 28-34 weeks' gestation with RDS would increase log odds of BDP by 0.005 $(\mathrm{p}=0.031)$ after adjustment for confounding factors of birth weight and gestational age. Increased in serum IL-6 levels within 6-12 hours after birth in preterm infants at 28-34 weeks' gestation with RDS was associated with an increased risk of BPD.
\end{abstract}

Keywords: respiratory distress syndrome, preterm infants, bronchopulmonary dysplasia, cytokine, interleukin-6

Cite This Article: Ayu Alia, Fiva A Kadi, Tetty Yuniati, Aris Primadi, Sjarief Hidajat, and Abdurachman Sukadi, "Relationship between Serum Interleukin-6 Levels and Bronchopulmonary Dysplasia in Preterm Infants at 28-34 Weeks' Gestation with Respiratory Distress Syndrome.” American Journal of Clinical Medicine Research, vol. 7, no. 1 (2019): 26-30. doi: 10.12691/ajcmr-7-1-5.

\section{Introduction}

Respiratory distress syndrome is a respiratory disorder that occurs due to deficiency of surfactants and can reduce lung development ability $[1,2,3,4]$. There is a hypothesis that RDS in newborns has a complicated pathogenesis and is influenced by many factors that are characterized by an inflammatory process and damage to the immature lung $[5,6]$. Local and systemic inflammations, seems to play an important role in the pathogenesis of RDS [7]. Up to $40 \%$ of RDS may develop BPD [6]. Respiratory distress syndrome can occur with ventilation perfusion mismatch that causes hypoxia, oxygen dependency, increased oxidative stress and inflammatory processes and increases the use of respiratory support which can ultimately increase the risk of BPD [5,6]. Developing theory is that intrauterine pro-inflammatory cytokines may play an important role in the occurrence of BPD. Pro-inflammatory cytokines play an important role in lung damage to preterm infants who subsequently develop BPD [6].

The incidence of BPD has increased over the past few decades as a result of increasing survival of very low birth weight (VLBW) infants who need mechanical ventilation. Early detection is very important to prevent the occurrence of chronic pulmonary remodeling and complications later in life. Bronchopulmonary dysplasia is often difficult to diagnose and prevent due to a lack of good biomarkers to identify infants at risk and symptoms that often overlap with other diseases, such as pulmonary hypertension. As a result of the limited effective management available for BPD, studies are focused primarily on prevention strategies and identification of biomarkers for early detection [8]. Pathomechanism of systemic cytokines in lung injury in preterm infants is still unclear. There are several possibilities including: cytokine concentration increases after hypoxia, which contributes damaging the lung cells through an inflammatory mechanism $[6,9]$. The imbalance between inflammatory and anti-inflammatory 
mechanisms activates the inflammatory response in the lungs of infants with RDS [9]. Interleukin-6 (IL-6) is an inflammatory product that is widely expressed in the lungs of mice that are being formed and can interfere the alveolarization process [10]. Increased levels of proinflammatory cytokines in the airway and lung tissue in preterm infants are associated with their inability to control the inflammatory process through expression of anti-inflammatory cytokines. An imbalance between pro and anti-inflammatory cytokines is an important risk factor for BPD [11,12,13].

Interleukin-6 is a multifunctional cytokine that is involved in regulating immune response, hematopoiesis, acute phase response and inflammation. Interleukin-6 is a pro-inflammatory cytokine produced by various types of cells in response to infection and non-infection also as one of the most expressed inflammatory mediators $[14,15,16]$. In the group of healthy near term infants the median IL-6 concentration at 16 hours after birth was 10.9 $(6,53-18,4) \mathrm{pg} / \mathrm{mL}$ [15]. In a study conducted by Lusyati et al in 2013, IL-6 levels of preterm infants at $\leq 32$ weeks' gestation were $12(1-251) \mathrm{pg} / \mathrm{mL}$ taken at 4 hours after birth [17].

Some studies have demonstrated increased levels of serum IL-6 level in RDS and was associated with BPD. An increase in serum IL-6 levels at 4 hours after birth was associated with the incidence of BPD in preterm infants [18]. Serum IL-6 levels in cord blood was increase in RDS and BPD [19,20]. There was an increase in serum IL-6 levels in cord blood and tracheal aspirates for infants who developed BPD later in life [11]. The cut-off point of IL-6 levels was $>46.125 \mathrm{pg} / \mathrm{mL}$ showed a good predictive effect for BPD when used in infants with $<30$ weeks' gestation. Median serum IL-6 level was 47 (0.70-179.75) $\mathrm{pg} / \mathrm{mL}$ in BPD infants with gestational age $\leq 32$ weeks taken at birth [21].

Study on the relationship between serum interleukin6 levels and BPD in 28-34 weeks preterm infants with RDS in Indonesia has never been done. The aim of the study was to find out the relation of serum IL-6 levels and BPD in preterm infants at 28-34 weeks' gestation with RDS.

\section{Methods}

A cross-sectional study was conducted in June-September 2018. Subjects were consecutively selected from preterm infants at 28-34 weeks' gestation with RDS born at Dr. Hasan Sadikin Hospital Bandung. Exclusion criteria: infants suffering from congenital major abnormalities, maternal clinical chorioamnionitis, a clinical diagnosis is made if mother had fever $>38^{\circ} \mathrm{C}$ and was accompanied with two or more of the following signs: leukocytosis $>15000$ cells $/ \mathrm{mm}^{3}$, fetal heart rate $>160$ beats/minute, maternal pulse $>100$ times/minute, uterine tenderness when not contracting, bad smell of the amnion fluid. And premature rupture of membranes (PROM) for more than 18 hours.

Approximately $1,5 \mathrm{ml}$ of venous blood sample collected within 6-12 hours after birth for IL-6 examination using Elabscience ${ }^{\circledR}$ Human interleukin 6 ELISA Kit. Catalog Number: E-EL-H0102. Detection limit were 4,69 pg/mL
[22]. Diagnosis of RDS is marked clinically by: respiratory rate $>60$ times per minute. chest wall retraction, grunting, cyanosis in room air, radiological $(+)$ towards RDS, blood gas analysis found $\mathrm{PaO} 2$ levels $<40 \mathrm{mmHg}$ at the age of less than 1 hour, $<60 \mathrm{mmHg}$ at the age of more than 1 hour, $\mathrm{PaCO} 2$ levels $>50 \mathrm{mmHg}$, more than four criteria and does not improve within 24 hours diagnosed as RDS [6]. At 36 weeks' PMA or discharge to home whichever came first, a clinical diagnosis of BPD was performed. The clinical criteria for BPD are in accordance with BPD clinical criteria according to the 2001 NICHD [11,23]. Infants were followed-up to determine whether they developed BPD.

Antenatal and postnatal risk factors for BPD development were recorded. A detailed history from mothers, including maternal age, antenatal steroid use, maternal risk factor, history of maternal disease and route of delivery, was obtained. The gestational history of the infants, including birth weight, gestational age, gender, Apgar scores, presence of neonatal morbidities such as severe infections consisting of necrotizing enterocolitis (NEC) and sepsis was recorded. Duration of respiratory support, duration of total supplemental oxygen, and hyperoxia $\left(\mathrm{FiO}_{2} \geq 40 \%\right)$ were also recorded. Statistical analysis was performed using the SPSS for windows version 23.0 (SPSS Inc., Chicago, IL, USA). A logistic regression test was performed to find out the correlation between serum IL-6 levels and BPD in preterm infants at 28-34 weeks' gestation with RDS.

\section{Results}

A total of 76 infants met the study inclusion criteria, while eight other infants were not included in the study for the following reasons: six infants died before 7 days of age and two other infants went home at the request of parents before the observation time was over.

Of the 68 babies who were included in the study criteria consisted of 43 (63.2\%) male infants and 25 (36.8\%) female infants, with a gestational age range between 2834 weeks. Based on age classification, subjects were dominated by infants at 28-32 weeks' gestation as many as $42(61.8 \%)$, with a mean gestational age of $31.6(1.57)$ weeks. Based on BPD the subjects were grouped into: 10 developed BPD and 58 were not. The general characteristics of the study subject can be seen in Table 1.

Table 2 shows that preterm infants 28-34 weeks' gestation who developed BPD were 10 (14.7), the median of gestational age in BPD infants was 31.5 (29-33) and mean birth weight who developed BPD was 1396 (284.9) grams. Half of infants who developed BPD have received antenatal steroids and experience severe respiratory distress. More antenatal steroids are given to infants who do not develop BPD. Eighty percent of babies with BPD have received oxygen exposure of $\geq 40 \%$. The median duration of respiratory support in infants with BPD was 21.5 (14-61) days and the median duration total supplemental oxygen was 44 (32-67) days. To determine the relationship between serum IL-6 levels in preterm infants at 28-34 weeks' gestation with RDS and BPD a logistic regression test was performed. 
Table 1. General Characteristics of Preterm Infants At 28-34 weeks' Gestation with RDS

\begin{tabular}{|c|c|}
\hline Characteristics & $\mathrm{n}=68$ \\
\hline \multicolumn{2}{|l|}{ Preterm Infants } \\
\hline \multicolumn{2}{|l|}{ Sex: n (\%) } \\
\hline Male & $43(63,2)$ \\
\hline Female & $25(36,8)$ \\
\hline Birth Weight (gram), mean (SD) & $1528(271,8)$ \\
\hline \multicolumn{2}{|l|}{ Birth Weight Category, n (\%) } \\
\hline $1500-<2500$ & $39(57,3)$ \\
\hline $1000-<1499$ & $28(41,2)$ \\
\hline$<1000$ & $1(1,5)$ \\
\hline Gestational Age (weeks), median (range) & $32(28-34)$ \\
\hline \multicolumn{2}{|l|}{ Gestational Age Cathegory, (weeks) n (\%) } \\
\hline $28-32$ & $42(61,8)$ \\
\hline $33-34$ & $26(38,2)$ \\
\hline APGAR Score at 1 minute, median (range) & $6(2-8)$ \\
\hline APGAR Score at 5 minute, median (range) & $8(5-10)$ \\
\hline \multicolumn{2}{|l|}{$\begin{array}{l}\text { Respiratory Distress Grading } \\
\text { Downes Score (DS), n (\%) }\end{array}$} \\
\hline Moderate (DS 4-5) & $61(89,7)$ \\
\hline Severe (DS $\geq 6$ ) & $7(10,3)$ \\
\hline \multicolumn{2}{|l|}{ Surfactan Therapy, n (\%) } \\
\hline Yes & $2(2,9)$ \\
\hline No & $66(97,1)$ \\
\hline \multicolumn{2}{|l|}{ Oxygen Fraction, n (\%) } \\
\hline Hyperoxia $\left(\mathrm{FiO}_{2} \geq 40 \%\right)$ & $12(17,6)$ \\
\hline No Hyperoxia $\left(\mathrm{FiO}_{2}<40 \%\right)$ & $56(82,4)$ \\
\hline Duration of Respiratory Support (days), median (range) & $5(2-61)$ \\
\hline $\begin{array}{l}\text { Duration Total Supplemental Oxygen (days), median } \\
\text { (range) }\end{array}$ & $8,5(3-67)$ \\
\hline \multicolumn{2}{|l|}{ Maternal } \\
\hline Age (year), mean (SD) & $29(6,9)$ \\
\hline \multicolumn{2}{|l|}{ Route of Delivery, n (\%) } \\
\hline Sectio Caesarea & $41(60,3)$ \\
\hline Spontaneous & $25(36,7)$ \\
\hline Spontaneous Breech & $1(1,5)$ \\
\hline Forcep Extraction & $1(1,5)$ \\
\hline \multicolumn{2}{|l|}{ Maternal Risk Factor, n (\%) } \\
\hline \multicolumn{2}{|l|}{ Preeclampsia dan Eclamspia } \\
\hline Yes & $17(25)$ \\
\hline No & $51(75)$ \\
\hline \multicolumn{2}{|l|}{ Antepartum Bleeding } \\
\hline Yes & $12(17,7)$ \\
\hline No & $56(82,3)$ \\
\hline \multicolumn{2}{|l|}{ Prematur Contraction } \\
\hline Yes & $24(35,3)$ \\
\hline No & $44(67,7)$ \\
\hline \multicolumn{2}{|l|}{ PROM $<18$ hours } \\
\hline Yes & $9(13,2)$ \\
\hline No & $59(86,7)$ \\
\hline \multicolumn{2}{|l|}{ Antenatal Steroid, n (\%) } \\
\hline Yes & $22(32,3)$ \\
\hline No & $46(67,6)$ \\
\hline \multicolumn{2}{|l|}{ History of Maternal Disease, n (\%) } \\
\hline \multicolumn{2}{|l|}{ Chronic Hypertension } \\
\hline Yes & $9(13,2)$ \\
\hline No & $59(86,7)$ \\
\hline \multicolumn{2}{|l|}{ Anemia } \\
\hline Yes & $3(4,4)$ \\
\hline No & $65(95,6)$ \\
\hline Diabetes Mellitus & \\
\hline Yes & $1(1,5)$ \\
\hline No & $67(98,5)$ \\
\hline
\end{tabular}

Table 2. Characteristic of Preterm Infants at 28-34 weeks' Gestation with or without BPD

\begin{tabular}{|l|c|c|}
\hline Characteristics & $\begin{array}{c}\mathrm{BPD}(+) \\
\mathrm{n}=10\end{array}$ & $\begin{array}{c}\mathrm{BPD}(-) \\
\mathrm{n}=58\end{array}$ \\
\hline $\begin{array}{l}\text { Sex } \\
\text { Male } \\
\text { Female }\end{array}$ & $\begin{array}{c}5(50) \\
5(50)\end{array}$ & $\begin{array}{c}20(34,5) \\
38(55,8)\end{array}$ \\
\hline $\begin{array}{l}\text { Gestational Age, (weeks) median } \\
\text { (range) }\end{array}$ & $31,5(29-33)$ & $32(28-34)$ \\
\hline Birth Weight (g), mean (SD) & $1396(284,9)$ & $1551(265,4)$ \\
\hline IL-6 (pg/mL) median (range) & $\begin{array}{c}60,5 \\
(4,83-882,7)\end{array}$ & $\begin{array}{c}44 \\
(4,8-454,3)\end{array}$ \\
\hline Antenatal Steroid, n (\%) & $5(50)$ & $41(71)$ \\
\hline Hyperoxia (FiO $2 \geq 40 \%), \mathrm{n}(\%)$ & $8(80)$ & $4(6,9)$ \\
\hline Severe Respiratory Distress, $\mathrm{n}(\%)$ & $5(50)$ & $2(3,4)$ \\
\hline $\begin{array}{l}\text { Duration of Respiratory Support } \\
\text { (days), median (range) }\end{array}$ & $21,5(14-61)$ & $5(2-12)$ \\
\hline $\begin{array}{l}\text { Duration Total Supplemental Oxygen } \\
\text { (days), median (range) }\end{array}$ & $44(32-67)$ & $7,5(3-18)$ \\
\hline $\begin{array}{l}\text { Mode of Respiratory Support, n (\%) } \\
\text { CPAP }\end{array}$ & $3(30)$ & $58(100)$ \\
Ventilator & $7(70)$ & $0(0)$ \\
\hline Severe Infection, n (\%) & $10(100)$ & $21(36,2)$ \\
\hline \multicolumn{2}{|l|}{} \\
\hline
\end{tabular}

Table 3. Logistic Regression of Serum IL-6 Levels and BPD by Adjusting Infant's Confounding Factor Variables

\begin{tabular}{|c|c|c|c|c|}
\hline Variables & $\mathrm{B}$ & $\mathrm{SE}$ & $\mathrm{p}$ & Adjusted OR (95\%CI) \\
\hline IL-6 & 0.005 & 0.002 & 0.031 & $1.005(1.000-1.010)$ \\
\hline Birth Weight & -0.002 & 0.003 & 0.485 & $0.998(0.993-1.003)$ \\
\hline Gestational Age & 0.158 & 0.441 & 0.718 & $1.172(0.494-2.779)$ \\
\hline
\end{tabular}

The results of the study listed in Table 3 show that every increase in $1 \mathrm{pg} / \mathrm{mL}$ of serum IL-6 levels from the normal value based on research by Chiesa et al [15] which is $10.9 \mathrm{pg} / \mathrm{mL}$, examined within 6-12 hours after birth in preterm infants at 28-34 weeks' gestation with RDS will increase the log odds of BPD by $0.005(\mathrm{p}=0.031)$ after adjusting for confounding factors for birth weight and gestational age.

Other factors that might influence BPD in this study such as oxygen fraction, severe infection, duration of respiratory support and duration total of supplemental oxygen has not been able to be analyzed in the logistic regression because there was complete separation of data distribution.

Table 4. Logistic Regression of Serum IL-6 and BPD by Adjusting Maternal Confounding Factors Variables

\begin{tabular}{|l|c|c|c|c|}
\hline Variables & B & SE & p & $\begin{array}{c}\text { Adjusted OR } \\
(95 \% C I)\end{array}$ \\
\hline IL-6 pg/mL & 0,006 & 0,003 & 0,015 & $1,006(1,001-1,011)$ \\
\hline PROM <18 hours & $-0,747$ & 1,604 & 0,641 & $0,474(0,020-10,990)$ \\
\hline Premature contraction & $-1,063$ & 1,465 & 0,468 & $0,345(0,020-6,097)$ \\
\hline $\begin{array}{l}\text { Antepartum } \\
\text { bleeding }\end{array}$ & $-0,814$ & 1,477 & 0,581 & $0,443(0,025-8,006)$ \\
\hline $\begin{array}{l}\text { Pre-Eclampsia } \\
\text { and Eclampsia }\end{array}$ & $-0,883$ & 1,456 & 0,544 & $0,413(0,024-7,171)$ \\
\hline Antenatal steroid & $-0,487$ & 0,841 & 0,562 & $0,614(0,118-3,191)$ \\
\hline Route of birth & 0,045 & 0,985 & 0,963 & $1.046(0,152-7,208)$ \\
\hline $\begin{array}{l}\text { History of maternal } \\
\text { disease }\end{array}$ & $-0,651$ & 1,162 & 0,575 & $0,521(0,053-5,089)$ \\
\hline
\end{tabular}

The results of the study listed in Table 4 show that every increase in $1 \mathrm{pg} / \mathrm{mL}$ of serum IL-6 levels from the 
normal based on research by Chiesa et al [15] which is $10.9 \mathrm{pg} / \mathrm{mL}$, examined within 6-12 hours after birth in preterm infants at 28-34 weeks' gestation with RDS will increase the log odds of BPD by $0.006(p=0.015)$ after adjustments of maternal confounding factors, which are PROM, premature contractions, antepartum bleeding, pre-eclampsia and eclampsia, antenatal steroid administration, route of birth and history of maternal disease.

\section{Discussion}

The results of the 68 subjects from preterm infants at 28-34 weeks' gestation with RDS in this study were dominated by male sex. This is in accordance with the studies that male sex is a risk factor for RDS, rationalization of this relationship still cannot be explained with certainty. However, it is suspected that in female infants produce pulmonary surfactant earlier than male infants, possibly due to different hormonal profiles in male infants [24,25]. Androgens delay the secretion of pulmonary fibroblasts, which can delay the development of type II alveolar cells, thereby reducing surfactant production. Androgen slows fetal lung development by regulating the signaling pathway of epidermal growth factors and changing transforming growth factor-beta. Conversely, estrogen increases surfactant synthesis, including phospholipids, lecithin and surfactant proteins A and B, improving fetal lung development by increasing the number of type II alveolar cells and synthesis of lamellar bodies [25].

In this study, serum IL-6 levels increased in almost of preterm infants at 28-34 weeks' gestation with RDS. A case-control study reported that serum IL-6 levels at 4872 hours after birth of preterm infants with RDS were higher than those of healthy preterm infants [7].

Data from 68 subjects showed that 10 infants developed BPD, and 58 infants did not. Bronchopulmonary dysplasia found in this study was $14.7 \%$. Based on data characteristics of preterm infants 28-34 weeks' gestation with RDS who developed BPD, the median gestational age was lower in BPD infants compared to those who did not. The results of these studies are in accordance with the studies which shows that gestational age is inversely proportional to the incidence and severity of BPD [26,27].

There was a tendency for an increase in higher serum IL-6 levels taken in preterm infants within 6-12 hours after birth at 28-34 weeks' gestation with RDS which later developed BPD compared with those who did not. Koksal et al, reported that there was an increase in serum IL-6 levels taken in the first 24 hours of life in infants with BPD later in life. Interleukin-6 is a pro-inflammatory cytokine that can induce the inflammatory process, recruit and stimulate inflammatory cells. Cytokines also participate in lung development, mediating acute lung injury, and worsening lung injuries associated with ventilator use. Some pro-inflammatory cytokines including IL-6 are synthesized by alveolar macrophage cells, fibroblasts, type II pneumocytes and endothelial cells due to stimulation of hyperoxia, hypoxia, and endotoxin [11].

Serum IL-6 levels of some infants increased despite not developing BPD, this study only excluded maternal chorioamnionitis clinically not based on histopathology. Preterm births could be caused by subclinical chorioamnionitis from pregnant women. Clinical maternal chorioamnionitis is absent but there is inflammation of the placenta by histopathology and can be accompanied by PROM or not [28]. Another possibility is the presence of cytokine gene polymorphisms which can cause high cytokine concentrations even though the degree of lung injury is the same [18].

There were several infants with normal IL-6 levels but then developed BPD, this was probably due to other factors that could affect BPD in infants, these infants had hyperoxia during treatment and also had mechanical ventilation therapy over 7 days. Preterm infants at 28-34 weeks' gestation with RDS exposed to oxygen with a concentration of $\geq 40 \%$ more developed to BPD. Experimental animal studies, reported that exposure to oxygen with a concentration of $\geq 40 \%$ for 7 days can cause an increase in pulmonary oxidative stress and persistent immune cells causing a chronic inflammatory process later in life. This chronic inflammation is likely due to the positive feedback cycle due to the production of cell reactive oxygen species (ROS) by inflammatory cells which results in more inflammatory cells in the lung. Exposure to oxygen with a concentration of $\geq 40 \%$ for 7 days can cause an increase in thickening of airway smooth muscle $[29,30]$. Oxygen toxicity can increase free radical production which can contribute to lung inflammation and remodeling in chronic pulmonary disease. Increased markers of oxidation levels indicate that newborns receiving high concentrations of oxygen therapy produce more ROS associated with BPD [31-35].

Infants with BPD in this study are less diverse so the cut-off point for serum IL-6 levels cannot be determined which can be used as an early marker of BPD in preterm infants at 28-34 week's gestation with RDS. There was complete separation data distribution of infant's confounding factors in this study so that other variables that might influence BPD cannot be included in the analysis. Analysis of confounding factors has not been combined between infant's and maternal factors.

Further studies are expected to be carried out with a larger number of subjects with a better calculation of the number of subjects, a longer study period, and multicenter studies.

\section{Conclusion}

Increased serum IL-6 levels within 6-12 hours after birth in preterm at 28-34 weeks' gestation with RDS was associated with an increased risk of BPD.

\section{References}

[1] Holme N, Chetcuti P. The pathophysiology of respiratory distress syndrome in neonates. Pediatric and child health. 2012; 22: 507-512.

[2] Hermansen CL, Lorah KN. Respiratory distres in newborn. Am Fam Physician 2007; 76: 987-994.

[3] Jackson JC. Respiratory distress in the preterm infant. In: Gleason CA, Devaskar SU, editor. Avery's Disease of The Newborn. $9^{\text {th }}$ Edition. Elsevier Saunders Inc. 2012. p. 644-657.

[4] Guttentag S. Respiratory Distress Syndrome. In: Eichenwald E, Hansen A, Martin C, Stark A, editors. Manual of Neonatal care, $8^{\text {th }}$ Edition. Wolters Kluwer. 2017. p. 437-445 
[5] Speer CP. Neonatal respiratory distress syndrome: an inflammatory disease? Neonatology. 2011;99:316-319.

[6] Hammoud MS, Raghupathy R, Barakat N, Eltomi H, Elsori D. Cytokine profile at birth and the risk of developing severe respiratory distress and chronic lung disease. J Res Med Sci, 2017; 22: 62.

[7] Varvarigou AA, Thomas I, Rodi M, Economou I, Mantagos S, Mouzaki A. Respiratory distress syndrome (RDS) in premature infants is underscored by the magnitude of Th1 cytokine polarization. Cytokine. 2012; 58: 355-360.

[8] Rivera L, Siddaiah R, Oji-Mmuo C, Silveyra GR, Silveyra P. Biomarkers for bronchopulmonary dysplasia in the preterm infant. Front. Pediatr. 2016;4: 33.

[9] Illiodromiti Z, Zygouris D, Sifakis S, Pappa KI, Tsikouras P, Salakos N, dkk. Acute lung injury inpreterm fetuses and neonates: mechanisms and molecular pathway. J Maternal Fetal Neonatal Med. 2013. [Online]. Available: http://informahealthcare.com/jmf. [Accessed Oct. 25, 2017].

[10] Balany J, Bhandari V. Understanding the impact of infection, inflammation, and their persistence in the pathogenesis of bronchopulmonary dysplasia. Front. Med. 2015; 2(90): 1-10.

[11] Koksal N, Kayik B, Cetinkaya M, Ozkan H, Budak F, Kilic S, dkk. Value of serum and bronchoalveolar fluid lavage pro-and anti-inflammatory cytokine levels for predicting bronchopulmonary dysplasia in premature infants. Eur. Cytokine Netw. 2012; 23: 29-35.

[12] Jobe, A.H. Mechanisms of lung injury and bronchopulmonary dysplasia. Am. J. Perinatol. 2016; 33: 1076-1078.

[13] Niedermaier S, Hilgendorrf A. Bronchopulmonary dysplasia-an overview about pathophysiologic concepts. Molecular and Cellular Pediatrics. 2015; 2: 1-7.

[14] Eric Z, Konjevic S. Proinflammatory cytokines in a newborn: a literature review. Signa Vitae. 2017; 13: 10-13.

[15] Chiesa C, Pacifico L, Natale F, Hofer N, Osborn JF, Resch B. Fetal and early neonatal interleukin-6 response. Cytokine. 2015.

[16] Tanaka T, Kishimoto T. Targeting interleukin-6: all the way to treat autoimmune and inflammatory diseases. Int. J. Biol. Sci. 2012; 8: 1227-36.

[17] Lusyati S, Hulzebos CV, Zandvoort J, Sauer PJ. Levels of 25 cytokines in the first seven days of life in newborn infants. BMC Research Notes. 2013. 6:547.

[18] Ambalavan N, Carlo WA, D’Angio CT, McDonald SA, Das A, Schendel D, dkk. Cytokines associated with bronchopulmonary dysplasia or death in extremely low birt weight infants. Pediatrics. 2009; 123: 1132-1141.

[19] Sorokin Y, Romero R, Mele L, Iams JD, Peaceman AM, Leveno $\mathrm{KJ}$, dkk. Umbilical cord serum interleukin-6, c-reactive protein, and myeloperoxidase concentrations at birth and association with neonatal morbidities and long term neurodevelopmental outcomes. Am J Perinatol. 2014; 31: 717-726.

[20] Paananen R, Husa AK, Voulteennaho R. Blood cytokines during the perinatal period in very premature infants: relationship of inflammatory response and bronchopulmonary dysplasia. J Pediatr. 2009; 154: 39.
[21] Tian XY, Zhang XD, Li QL, Shen Y, Zheng J. Biological markers in cord bloodfor prediction of bronchopulmonary dysplasia in premature infants. Clin Exp Obstet Gynecol. 2014; 41: 313-318.

[22] Elabscience. Human interleukin 6 ELISA Kit. Catalog no: E-EL-H0102. $7^{\text {th }}$ Edition. 2017.

[23] Kair LR, Leonard DT, Anderson JM. Bronchopulmonary dysplasia. Pediatrics in Review. 2012; 33: 255-263.

[24] Condo V, Cipriani S, Colnaghi M, Bellu R, Zanini R, Bulfoni C, dkk. Neonatal respiratory distress syndrome: are risk factors the same in preterm and term infants? J Matern Fetal Neonatal Med. 2017; 30(11): 1267-1272.

[25] Liu J., Yang N, Liu Y. High-risk Factors of Respiratory Distress Syndrome in Term Neonates: A Retrospective Case-control Study. Balkan Med J 2014; 31: 64-68.

[26] Zysman-Colman Z, Tremblay GM, Bandeali S, Landry JS. Bronchopulmonary dysplasia-trends over three decades. Pediatr. Child Health. 2013; 18: 86-90.

[27] Torchin H, Ancel P, Goffinet F, Hascoet JM, Truffert P, Tran D, dkk. Plasental complication and bronchopulmonary dysplasia EPIPAGE-2 cohort study. Pediatrics. 2016; 1 37(3): e20152163.

[28] Yüce O, Biçer OS, Kavuncuoğlu S, Ozelgün B, Ongüt C. Prematurity, infection, mortality, morbidity and interleukins: the reason or the result of preterm labor? Minerva Pediatr. 2014; 66: 563-70.

[29] Bouch S, O,Reilly M, Harding R, Sozo F. Neonatal exposure to mild hyperoxia causes persistent increases in oxidative stress and immune cells in the lungs of mice without altering lung structure. Ajplung. 2015; 309: L488-96.

[30] Wang H, Jafri A, Martin RJ, Nnanabu J, Farver C, Prakash S, dkk. Severity of neonatal hyperoxia determines structural and functional changes indeveloping mouse airway. Ajplung. 2014; 307: L295-301.

[31] Hsiao C, Chang J, Tsao L, Yang R, Chen H, Lee C, dkk. Correlates of elevated interleukin-6 and 8-hydroxy-2'-deoxyguanosine levels in tracheal aspirates from very low birth weight infants who develop bronchopulmonary dysplasia. Pediatrics and Neonatology. 2017; 58: 63-69.

[32] Davidson LM, Berkelhamer SK. Bronchopulmonary dysplasia: chronic lung disease of infancy and long-term pulmonary outcomes. J. Clin. Med. 2017; 6: 4.

[33] Berkelhamer SK, Kim GA, Radder JE, Wedgwood S, Czech L, Steinhorn RH, dkk. Developmental differences in hyperoxiainduced oxidative stress and cellular responses in the murine lung. Free Radic. Biol. Med. 2013; 61: 51-60.

[34] Yee M, White RJ, Awad HA, Bates WA, McGrath-Morrow SA, O'Reilly MA. Neonatal hyperoxia causes pulmonary vascular disease and shortens life span in aging mice. Am. J. Pathol. 2011; 178: 2601-2610.

[35] Datta A, Kim GA, Taylor JM, Gugino SF, Farrow KN, Schumacker PT, dkk. Mouse lung development and nox1 induction during hyperoxia are developmentally regulated and mitochondrial ros dependent. Am. J. physiol. Lung Cell. Mol. Physiol. 2015; 309: L369-L377. 